\title{
Local Government Units in
} Indonesia: Demographic Attributes and Differences in Financial Condition

\author{
Rusmin Rusmin ${ }^{1}$, Emita W. Astami², \& Glennda Scully³
}

\begin{abstract}
This study examines the outcome of decentralisation reforms in Indonesia, focusing on the association between demographic characteristics and differences in the financial condition of local governments units. It investigates crosssectional data pertaining to demographic characteristics and financial statements audited by the Supreme Audit Body of 419 Indonesian local government units for the fiscal year 2007. It utilises demographic attributes including scope of entity, location, tenure (date of entry), gender, human development index (HDI) and size of local governments to explain differences in the financial condition of Indonesia's local government. Local government financial condition is proxied by quick ratio, debt ratio, services ratio, and ratio of local to total revenues. The results suggest that scope and location of local government units help explain all of the financial condition variables. The findings further infer that local government units domiciled in Java tend to report better financial conditions relative to those domiciled in other islands. Our results also show that local government units with greater female populations and higher HDI are more likely to have a local authority that (1) has better ability to finance their general services from their unrestricted net assets, and (2) has greater ability to earn more revenues from local sources. Finally, this study documents that the larger the population of a local government unit, the higher its liquidity position, the stronger its ability to funding general services, and the greater its possibility earning revenues from its local sources.
\end{abstract}

Keywords: Demographic attributes, local government, financial condition, Indonesia

JEL Code: M40

\footnotetext{
${ }^{1}$ Universitas Teknologi Yogyakarta, Indonesia

${ }^{2}$ Universitas Teknologi Yogyakarta, Email: eastami@gmail.com

${ }^{3}$ Curtin University, Australia
} 


\section{Introduction}

The purpose of this study is twofold. First it investigates whether there are differences in financial condition of local governments in Indonesia. Second, it examines the association between demographic characteristics and financial condition of local government units in Indonesia. Decentralisation is one of the most important reforms undertaken by the Indonesian government after the democratic election of June 1999. As the decentralisation reform provides the framework for political and financial devolution through Laws 22/1999 and 25/1999, local governments incorporating regencies (rural districts) and cities (urban districts) and that are located in Java and Non Java have assumed new responsibilities that were previously covered by the central government. Indonesia has devolved a wide array of powers and resources to local government authorities. Furthermore, researchers suggest that decentralisation can affect spending efficiency (Boetti, Piacenza \& Turati 2010) and can also be a means of achieving productive efficiency as well as service costs (Chowdhury, Yamauchi \& Dewina 2009). On the other hand, USAID (2008) suggests that as local government units in Indonesia are very diverse in terms of culture, ethnic groups, language, religion, economy, and other social indicators, then the impact of the decentralisation reforms on the development varies among local government units. Therefore, this study scrutinises whether decentralisation in Indonesia shapes local governments' financial condition and whether demographic characteristics explain local governments’ financial condition.

After several years of taking advantage of reforms that resulted in increasing autonomy in administering their own areas, many local governments have increased their efforts to raise local revenues by introducing some local taxes, retributions and fees (Alm, Martinez-Vasquez \& Indrawati 2004). These authors also suggest that the importance of local own revenues in financing local government spending varies among local government units. The autonomy given to local government units will enable local governments to achieve the efficiency and that will come when governmental decisions are more responsive to the wishes of their citizens.

In Indonesia, the existing empirical studies on decentralisation primarily examine issues related, for example, to local infrastructure, per capita income and poverty rates (Chowdhury et al. 2009), challenges and opportunities to improve public service at the local level (USAID 2008), inter governmental transfer fund (Brojonegoro 2001) and local government borrowing (Alm et al. 2004). One further aspect to the case of the decentralisation reform in Indonesia that has been largely unexamined is the characteristics of local government units and their financial condition presented in their financial statements. In Indonesia, the decision to decentralise was exogenous to the local authorities, and the implementation of decentralisation was relatively quick; rather than executing gradualism. Therefore, it is timely to examine the local government achievements in term of their financial condition. In line with the purpose of the study, this paper attempts to answer two research questions. These are: (1) whether there are differences in financial condition of local governments between that of regencies and cities and between that of local governments located in Java and Non-Java, and, (2) how demographic characteristics explain the financial condition of local government units. 
This study utilises cross sectional data associated with demographic characteristics and financial statements of local government units for the fiscal year 2007. In this study, local government financial condition is measured by financial ratios including a combination of various ratios as indicated by prior research as being appropriate measures for local government. These ratios include quick ratio, debt to asset ratio (Kamnikar, Kaminkar \& Deal 2006; Suwarno 2007), continuing services ratio (Kamnikar et al. 2006) and total and local revenues per capita ratio (Hughes \& Laverdiere 1986) as indicators of the financial condition of Indonesian local government. In this study, different characteristics of local authorities including scope, location, tenure, gender and human development index, and size are used as predictors for financial condition of local government units in Indonesia. This is in line with Chatman and Flynn 2001; Lawrence 1997; Roszak 2006; Stevens 2005; Wei et al. 2005. They provide empirical evidence that demographic variables, such as gender, age, education level, income level, employment concentration, and population growth influence the financial condition of a government authority.

Findings from examining the outcome of the decentralisation reform in Indonesia in the context of demographic characteristics and the financial condition of local government units in Indonesia will provide some contributions. The first contribution is to the enhancement of an emerging body of literature in decentralisation reforms and their effect on the financial condition of local governments. Additionally, these findings also aid in identifying which demographic attributes of local government units determine their financial condition following the decentralisation reform. Finally, this study provides specific localised insights to local authorities, Indonesian Central Governments, as well as international institutions such as the Asian Development Bank in reviewing and developing their funding for development programs in Indonesia.

The remaining paper is organised as follows. Section 2 is an overview of decentralisation and local governments' financial accountability in Indonesia. This is followed by a discussion literature review in Section 3. A description of the sample and research approach is presented in Section 4. Section 5 highlights the key descriptive and statistical findings. Discussion and conclusions including considerations of future research are advanced in Section 6.

\section{Decentralisation and Local Government Financial Accountability}

Decentralisation refers to the devolution of decision making power on local policies to the elected local-level authorities of the relevant localities. The main objective of decentralisation in Indonesia was to promote better delivery of government services and improved local government accountability. The Republic of Indonesia is divided into 33 provinces which are further divided into regencies and cities. Province, regencies, and cities, have their own local governments and parliamentary bodies.

Post Soeharto, since 1 January 2001, the major regional autonomy program was introduced as a means of accommodating regional issues with the central government. It was initiated by adapting two laws (Laws 22 and 25) relating to decentralisation in 1999. These new laws resulted in many changes to the nature and style of Indonesia's governance. Law 22/1999 focuses on the devolution of local government authority, while Law 25/1999 deals with how 
decentralisation is financed, thus it incorporates the rearrangement of the fiscal responsibility between the central government and the local government (Ray \& Goodpaster 2003). The enactment of Law 22/1999 regarding Local Government (the law was revised by Law 32/2004) meant local governments have enjoyed greater self-administration and autonomy. Issues that continue to be determined by the central government include foreign policy, defense (including armed forces and national police), system of law, fiscal and monetary policy (Sukma 2003; Usman 2001). Since 2005, heads of local government (governors, regents, and mayors for province, regencies and cities, respectively) have been directly elected by popular election.

By shifting more authority from the central to local government units in managing their affairs, it was also expected that the development programme would improve the local governments', as well as Indonesia's, economic conditions. Accordingly, the central government (Government of the Republic of Indonesia, thereafter referred to as GOI) urgently called for good governance in managing local government finances to provide better services for Indonesian citizens. For this reason, the GOI and the House of Representatives introduced a new package consisting of four laws that affected state financial reform. These are Law 17/2003 on State Finance, Law 1/2004 on State Treasury, Law 15/2004 on Audit of State Financial Management and Accountability, and Law 32/2004 on Local Government. Amongst other things, those laws incorporate the obligation of central as well as local governments to present financial statements. Accordingly, the Government Accounting Standards or Standar Akuntansi Pemerintahan (SAP) were promulgated under Government Regulation No. 24/2005 and prepared by the Government Accounting Standard Committee (GASC). Thus, it became a legally enforceable approach to improve the quality of government financial statements in Indonesia. The application of SAP was effective for the financial statements from the budget year 2005. The government financial statements consist of the Statement of Budgeting Realization, the Statement of Financial Position, the Statement of Cash Flow, and the Notes to the Financial Statements. These financial statements are intended to fulfil the general purpose of financial reporting requirements.

\section{Review of the Literature}

Previous research provides empirical evidence that demographic variables, such as gender, age, education level, income level, employment concentration, and population growth influence the financial condition of a government authority in several countries (see Chatman \& Flynn 2001; Lawrence 1997; Roszak 2006; Stevens 2005; Wei et al. 2005). Recent studies also document that many small United States hospitals achieve a higher credit rating from Moody's Investor Service because of their favourable demographic characteristics (Roszak 2006). Additionally, the impact of demographic characteristics such as gender, age, tenure, educational level, and race on organisational condition have been explored from a variety of theoretical perspectives (e.g. Bantel 1993; Mannix \& Neale 2005; Roszak 2006; Thrane 2008; Wei et al. 2005; Young \& Buchholtz 2002).

Researchers (e.g. Goldberg 2005; Mannix \& Neale 2005; Young \& Buchholtz 2002) typically apply three primary theoretical perspectives: the similarity-attraction paradigm, the communication perspective, and the social 
identity theory, to explain the effects of these demographic attributes on organisational outcomes. According to similarity-attraction tenets, similarity of demographic attributes between two groups leads to perceived similarity in attitudes, values, and beliefs which in turn, facilitates interpersonal attraction between the two groups. Furthermore, this interpersonal attraction will lead to a favourable approach to the other group (Goldberg 2005; Judge \& Ferris 1993; Mannix \& Neale 2005; Young \& Buchholtz 2002). In contrast, the communication perspective suggests that individuals who have similar social, education, and work experience will create a common language that facilitates communication and contributes to a positive outcome (Young \& Buchholtz 2002; Zenger \& Lawrence 1989). Finally, the social identity theory posits that individuals determine their social identity by categorising themselves and others and then identifying more with members of their own category (in-group) than with out-group members (Hogg \& Terry 2000; Turner \& Oakes 1986;). On the other hand, people who differ in demographic attributes create social divisions that, in turn, will create poor communication, poor social interaction and cohesion, resulting in less productive work (Mannix \& Neale 2005; Young \& Buchholtz 2002). However, optimistic proponents of diversity argue that heterogeneity creates value and the opportunity for improving organisational performances as people in diverse groups tend to communicate with other people from different backgrounds, networks, information, and skills. These interactions enhance the group performance (Cox, Lobel \& McLeod 1991; Gruenfield et al. 1996; Levine \& Resnick 1993).

Previous research on local governments has scrutinised performance and financial condition of local governments by using financial ratios (Carmeli 2004; Chaney 2005; Groves, Godsey \& Shulman 1981; Kamnikar et al. 2006; Pallis \& Syriopoulos 2007; Stevens \& McGowan 1983). They argue that this technique of analysis is appropriate for use by an analyst in evaluating the state or local government financial statements. However, there is no consensus in relation to which ratios that are considered to best demonstrate financial position and performance of a local government authority (Chaney, Mead \& Schermann 2002; Kamnikar et al. 2006). Zeller, Stanko and Cleverley (1996) also argue that not all financial ratios may be necessary for meaningful insights. This study, therefore, utilises a combination of various ratios as indicated by prior research as being appropriate measures for local government. Specifically, this study uses Quick Ratio, Debt to Asset Ratio (Kamnikar et al. 2006; Suwarno 2007), Continuing Services Ratio (Kamnikar et al. 2006) and Total and Local Revenue per Capita (Hughes \& Laverdiere 1986) as indicators of the Indonesian local government financial condition. The use of those ratios are also in line with the Government Regulation No. 24 Year 2005 (President of the Republic of Indonesia 2005). Suwarno (2007) suggests that the liquidity and solvency ratios should be utilised for evaluation of the government financial condition.

This study utilises demographic attributes incorporating scope, location, tenure (date of entry), gender, human development index and size, to explain the financial condition of local government units in Indonesia. As the Republic of Indonesia is divided into provinces and each province consists of regencies and a city, this study classifies the scope of local government into city (kota) and regency (kabupaten). Regencies have a larger area than cities and, generally, cities are characterised by non-agricultural economic activities. Each regency is 
headed by a regent (bupati), and each city is headed by a mayor (walikota). City and regency are technically the same level of government. The distinction is based on whether the government administration is located in an urban or a rural area. Local authorities that are located in an urban, a central point or metropolitan area, are considered as a city, while those located in a rural area are known as regencies. In addition, city local authorities are generally characterised by traffic congestion, dense population, more pressure from provincial or central governments, and greater media concentration. Prior research suggests that local governments encompassing a metropolitan centre face different pressures than their rural counterparts. City local authorities might have greater pressure to provide better quality of public facilities and services compared to the regency local governments (Pilcher \& Van der Zhan 2008). These clear differences between city and regency local government authority have the potential to impact on the financial condition of local governments.

Location of local governments is categorised as Java and outside Java. Java is by far the most populous island in Indonesia, with approximately $59 \%$ of the country's population. With 155 million inhabitants at 3,050 people per $\mathrm{km}^{2}$, it is also one of the most densely-populated parts of the world (Statistics Indonesia 2005). Approximately 45\% of the population of Indonesia is ethnically Javanese. Only two major ethnic groups are native to the island - the Javanese and Sundanese. The Javanese comprise about two-thirds of the island's population. Outside Java, Indonesia consists of six main islands: Sumatera, Kalimantan, Sulawesi, Madura, Bali, and Lombok. They are very diverse in terms of culture, ethnic groups, language, religion, economy, and other social indicators. For example, they originate from many different cultures and ethnic groups and speak hundreds of different regional languages.

This study categorises the date of entry (tenure) of local government units into two groups. One group incorporates local government units that have existed since 1 January 2001 as a result of the decentralisation reform as new local government units and the other group is old local government units consisting of local governments that existed before 1 January 2001.

Gender may also influence the financial condition of local authorities. Throughout Indonesia, women are a powerful force for growth and development, making important contributions to the economy as workers and entrepreneurs, and to the welfare of their families. In many cases, however, unequal access to property, discrimination in the labour market, and business-related obstacles hinder women from contributing even more to their local governments' growth and well-being. Exploring the possible determinants of the impact of gender on the financial condition of local governments can provide insights for policy makers by identifying obstacles to their efforts in empowering women. By removing identified obstacles the government and local authorities can help not only empower women, but also to unlock the full economic potential of the nation. The issue of gender also occurs in an organisation. Pfeffer (1997), for example, argues that firms can be described in terms of a number of gender compositions. Frink et al. (2003) suggest a nonlinear relationship between gender diversity and firm performance. That is, low firm performance is associated with a very low or very high proportion of females, whereas a moderate level of female representation relates to a high or very low effective performance of firms. In line with Frink et al. (2003), Brever (1991) also found a relationship between 
gender diversity and firm performance at different levels of analysis. Therefore, this study explores gender as a determinant of the financial condition of local government.

Another predictor of the financial condition of local authorities is the human development index (HDI). This index provides a broadened prism for viewing human progress and the complex relationship between income and wellbeing. It comprises a composite measure of three dimensions of human development: living a long and healthy life (measured by life expectancy), being educated (measured by adult literacy and enrolment at the primary, secondary and tertiary level) and having a decent standard of living (measured by purchasing power parity). The final predictor in this study is the size of local government, which is measured by the number of people who live in a given local authority. The rationale in using this variable is that the bigger the population of a local government, ceteris paribus, the greater the probability that it has greater resources and consequently the better its financial condition will be.

\section{Research Methodology}

\subsection{Sample Selection}

The data is drawn from the population of local government units in Indonesia for the year 2007.

\section{Table 1}

Sample Selection Process

\begin{tabular}{lc}
\hline \multicolumn{1}{c}{ Panel A: Original sample } & Number \\
\hline Description: & 440 \\
\hline $\begin{array}{l}\text { Total numbers of regencies and cities } \\
\text { Less: Number of regencies' and cities' financial statements that are not audited }\end{array}$ & \\
by the Supreme Audit Body & $(21)$ \\
Original sample - number of regencies' and cities' financial statements that are & \\
audited by the Supreme Audit Body
\end{tabular}

audited by the Supreme Audit Body

Panel B: Final sample for analysing quick ratio

Number of regencies' and cities' financial statements that are audited by the Supreme Audit Body

Financial statements with insufficient information to construct quick ratio and other demography proxy measures

Sample with quick ratio figures

\begin{tabular}{lc} 
Sample with quick ratio figures & 331 \\
\hline \multicolumn{1}{c}{ Panel C: Final sample for analysing debt ratio } & \\
\hline $\begin{array}{l}\text { Number of regencies' and cities' financial statements that are audited by the } \\
\text { Supreme Audit Body }\end{array}$ & 419 \\
$\begin{array}{l}\text { Financial statements with insufficient information to construct debt ratio and } \\
\text { other demography proxy measures }\end{array}$ & 353 \\
Sample with debt ratio figures & \\
\hline \multicolumn{2}{c}{ Panel D: Final sample for analysing continuing services ratio }
\end{tabular}

Number of regencies' and cities’ financial statements that are audited by the Supreme Audit Body

Financial statements with insufficient information to construct continuing service ratio and other demography proxy measures

Sample with continuing-services-ratio figures 
Audited financial statements are collected from the Supreme Audit Body's website. The demographic proxies (including scope and location) and the information regarding the tenure and population of the local governments are collected from the Minister of Home Affairs website. In addition, gender and HDI information is collected from the BPS-Statistics Indonesia website.

The population of regencies and cities in Indonesia is 440 units. Amongst those populations, information pertaining to 21 (local government) units was unavailable. Therefore, this study utilises the data from the remaining 419 units, in which, each unit provides a different level of financial report completeness. Table 1 provides details of information availability of each financial variable measure from the 419 entities. It shows that the availability of financial figures for calculating the financial ratios vary among local governments. There are 331, 353, 394 and 398 local government units that present data for calculating quick ratio, debt ratio, service ratio, and ratio of local to total revenues; consecutively.

\subsection{Measures of Financial Condition and Demography Variables}

Groves et al. (1981) suggest that the term "financial condition” has many different meanings. It can refer to cash solvency, budgetary solvency, long-run solvency as well as service level solvency. However, Chaney et al. (2002) and Kamnikar et al. (2006) claim that there is some consensus concerning financial condition. They suggest that financial condition is a local government's ability, sustainability, flexibility, and vulnerability in the context of overall economic and financial environment. Therefore, the financial condition of a local government unit can be defined as 'a government's ability to meet its obligations as they fall due and the ability to continue providing the services its constituency requires (Kamnikar et al. 2006). There are also broad arrays of financial ratios that are available within each of the financial condition classifications (financial position, financial performance, liquidity and solvency). However, there are only a few ratios that may be relevant for evaluating local government financial performance (Watkins 2000; Zeller et al. 1996). There is a little agreement about what commonly accepted financial ratios are and how they should be measured (Chaney et al. 2002; Kamnikar et al. 2006).

To measure the financial condition of local government, this study utilises financial ratios that are used by Hughes and Laverdiere (1986), the Government Regulation (President of the Republic of Indonesia 2005) No. 24, Kamnikar et al. (2006), and Suwarno (2007). These are Quick Ratio, Debt Ratio, Continuing Services Ratio and Proportion of Revenues from Local Sources.

The Quick Ratio is an important variant of liquidity ratios and is used to evaluate a government's ability to pay its currently maturing financial obligations (Kamnikar et al. 2006; Nikolai \& Bazley 1994). This is a more conservative approach to measuring liquidity because it only considers Quick Assets that have a relatively short period to convert into cash. Unlike current assets, quick assets include cash, current investments, and accounts receivable.

The Debt Ratio indicates the percentage of total assets financed by creditors. This ratio measures the degree to which a government's assets are financed through borrowing and other long-term obligations (Mead 2001). The 
lower the Debt Ratio is the better the protection to creditors. It means that local governments have contributed a higher percentage of the funds in utilising assets for providing public services.

The Continuing Services Ratio is a ratio to measure financial condition as suggested by Chaney et al. (2002) and Chaney (2005). This ratio is a financial condition indicator that concentrates on the government's ability to maintain the provision of its basic services. This ratio indicates the degree to which the government's unrestricted net assets can support their continuing general services to the citizenry and better delivery of government services. The higher the ratio, the greater the unrestricted net resources that have been accumulated for financing costs.

The \%Local Revenues indicates the level of locally-sourced revenues gathered by a local authority. Analysts might prefer to identify a locality's revenues capacity from local sources (Hughes \& Laverdiere 1986). Law 25 of 1999 allows local governments to raise funds from (1) local source; (2) central government (for example, a general allocation and a special allocation fund for local governments); (3) local borrowings; and (4) other legal revenues in the local government authorities. Local government authorities' potential revenue sources include service fees, local taxes (taxes on electricity, hotels and restaurants, motor vehicles and transfers of titles and registrations) and user charges (health services provided by local public health services), the issuance of building permits and public market fees. Other own-source revenues include those generated by local government enterprises and interest income on unspent balances. The larger the locally-sourced revenue of a local government, the stronger is its capacity to finance its public services, therefore providing better delivery of government services.

Three demography variables used in this study (scope, location and tenure) are dichotomous variables. Gender, HDI and size are continuous variables. The details of the proxy measures for the dependent and independent variables are defined in Table 2.

Table 2

Variable Definition and Description

\begin{tabular}{|l|c|}
\hline Variable Description & Variable Title \\
\hline Dependent Variable & \\
\hline Cash, short-term investment, and receivables divided by current liabilities & Quick Ratio \\
\hline Total liabilities divided by total assets & Debt Ratio \\
\hline Unrestricted net assets divided by expenses & Services Ratio \\
\hline Revenues from local sources divided by total revenues & \%Local Revenues \\
\hline & \\
\hline Independent Variables & Scope \\
\hline $\begin{array}{l}\text { Indicator variable with a local government is scored one (1) if it is a city } \\
\text { and a regency is scored zero (0) }\end{array}$ & Location \\
\hline $\begin{array}{l}\text { Indicator variable with a local government is scored one (1) if it locates in } \\
\text { Java; otherwise scored zero (0) }\end{array}$ & Tenure \\
\hline $\begin{array}{l}\text { Indicator variable with a local government is scored one (1) if it is a new } \\
\text { authority; otherwise scored zero (0) }\end{array}$ & \\
\hline
\end{tabular}


Rusmin et al. | Local Government Units in Indonesia

\begin{tabular}{|l|c|}
\hline Ratio male to female population & Gender \\
\hline $\begin{array}{l}\text { Human development index (consists of three dimensions of human } \\
\text { development: life expectancy, literacy rate and purchasing power parity) }\end{array}$ & HDI \\
\hline $\begin{array}{l}\text { Total population (based on population census for the year 2004 by } \\
\text { Indonesian Bureau of Statistics) }\end{array}$ & Size \\
\hline
\end{tabular}

\section{Descriptive and Statistical Analyses}

Table 3, Panels A and B, provides the descriptive statistics for the dependent and independent variables. Panel A shows the descriptive statistics for the continuous variables used in the regression model. Panel B reports details of the categorical variables.

Table 3

Descriptive Statistics

\begin{tabular}{lccccc}
\hline \multicolumn{2}{l}{ Panel A- Continuous variables } & & & & \\
& Mean & Median & $\begin{array}{c}\text { Std } \\
\text { Deviation }\end{array}$ & Minimum & Maximum \\
\hline Quick Ratio & 901.06 & 38.40 & $4,178.84$ & 0.24 & $44,812.35$ \\
Debt Ratio & 0.0102 & 0.0027 & 0.0246 & 0 & 0.2508 \\
$\begin{array}{l}\text { Continuing Services } \\
\text { Ratio }\end{array}$ & 2.51 & 2.25 & 1.59 & 0.39 & 18.54 \\
\%Local Revenues & 0.0593 & 0.0481 & 0.0480 & 0 & 0.5373 \\
Gender & 1.03 & 1.02 & 0.06 & 0.84 & 1.28 \\
HDI & 68.43 & 68.70 & 4.66 & 46.90 & 77.70 \\
Size & 495,483 & 270,748 & 564,259 & 11,829 & $4,049,631$
\end{tabular}

Panel B - Categorical variables

\begin{tabular}{lcc} 
& Frequency & Percentage \\
\hline Scope of entity & & \\
$\quad$ City & 85 & 20.29 \\
Regency & 334 & 79.71 \\
$\quad$ & \\
Location & & \\
$\quad$ Java & 107 & 25.54 \\
$\quad$ Outside Java & 312 & 74.46 \\
Tenure & & \\
$\quad$ New & 39 & 9.31 \\
$\quad$ Old & 380 & 90.69 \\
\hline Legend: See Table 2 for full definitions and descriptions for the study's dependent and independent variables.
\end{tabular}

Table 3 highlights the key demographic and financial data. The average of the Quick Ratio is 901.06, indicating an extremely high liquidity position of the Indonesian local governments. This figure is not unusual, according to Chaney (2005) it is typical of government institutions to maintain conservative cash 
management policies and, thus, much higher liquidity ratios compared to private organisations. However, the median (38.40) appears to be a better representation for this ratio with the high level of both skewness (7.06) and standard deviation $(4,178.84)$. The minimum value for the Quick Ratio does fall below one (specifically 0.24 ), which indicates that some local governments do not have adequate cash on hand to assure their current liabilities. This, of course, does not mean that they will not be able to pay their obligation on time; because normally current liabilities due are spread out within the year. The mean of the Debt Ratio is very low. This figure indicates that in the fiscal year 2007, local governments, on average, have only funded around $1 \%$ of their assets with borrowed funds. The Debt Ratio ranges from 0.00 to $25.08 \%$. This maximum value indicates that approximately a quarter of a local government's assets are financed by liabilities. In summary, these ratios show that for fiscal year 2007, the Indonesia local governments appear financially strong. Even though Law No. 25 Year 1999 gives substantial freedom for local authorities to finance their budget with borrowed funds, the amount of local borrowing is relatively small. This is because of the very strict limitations on local authorities borrowing has been maintained by the central government by issuing a Government Regulation on local borrowing (No. 107 Year 2000).

The Continuing Services Ratio indicates that local governments have sufficient unrestricted net assets to provide the same level of total services in the future. The minimum value for the Continuing Services Ratio (0.39) reveals that some of the local governments do not have enough unrestricted net assets to assure the continuity of services that they can provide to their citizens. Table 3 presents the information that there is only 5.84\% (23 out of 394) of local governments with an unfavourable ratio (with Continuing Services Ratio less than one). The proportion of revenues from local sources ranges from 0 to $53.73 \%$ with a mean of $5.93 \%$. The portion of revenues from local sources is mostly from regional tax and retribution. As this ratio measures a local government's financial capacity to support public service activities from its local sources, it means that the larger the proportion of local government revenues derived from its regional sources, the lesser dependence that local authority has on central government.

The ratio of male to female population in a local government ranges from 0.84 percent to 1.28 with a mean of 1.03 . Although the proportions are effectively the same between male and female, according to the National Social and Economic Survey 2005, the literacy rate of the Indonesian population aged 15 years and above of male compared to female is somewhat different ( 0.97 versus 0.89 , respectively). This implies that men provide more human capital than women. The average of HDI for overall Indonesian cities and regencies is 68.43, ranging from 46.90 to 77.70 . The local authority that has the lowest index is Kabupaten Pegunungan Bintang (situated in the Province of Irian Jaya; outside Java) while Kota Yogyakarta (located in the Province of Daerah Istimewa Yogyakarta; Java) is the local government that has the highest HDI index. Finally, Table 3 shows that, the average population of the local governments is 495,483 ranging from the smallest of 11,829 (Kabupaten Supiori) to the biggest of 4,049,631 (Kabupaten Bandung).

Panel B of Table 3 indicates that the proportion of cities to regencies used in this study is comprised of 85 cities (20.29\%) and 334 regencies (79.71\%). The majority (312 or 74.46\%) of the local authorities are located outside Java and 107 
(25.54\%) are located on Java island. Amongst local governments in Indonesia, there are 39 (9.31\%) regions in the study's sample that resulted from the process of administrative fragmentation or because of the splitting-off of regions as a result of the Indonesian central government's decentralisation agenda. The splitoff process occurred throughout the years 2003 to 2007.

Table 4 presents the statistical correlations between the variables in the regression model. The upper half of each panel reports Pearson pairwise correlation coefficients and the lower half reports Spearman correlation coefficients. 
AABFJ | Volume 8, no. 2, 2014

Table 4

Pearson and Spearman Correlation Matrix

\begin{tabular}{|c|c|c|c|c|c|c|c|c|c|c|}
\hline & $\begin{array}{l}\text { Quick } \\
\text { Ratio }\end{array}$ & Debt Ratio & $\begin{array}{c}\text { Continuing } \\
\text { Services } \\
\text { Ratio }\end{array}$ & $\begin{array}{l}\text { \%Local } \\
\text { Revenues }\end{array}$ & Scope & Location & Tenure & Gender & HDI & Size \\
\hline Quick Ratio & 1 & $-0.907 *$ & $-0.284^{*}$ & 0.050 & $-0.149 *$ & 0.073 & 0.015 & 0.038 & -0.046 & -0.018 \\
\hline Debt Ratio & $-0.907 *$ & 1 & 0.071 & -0.027 & $0.129 * *$ & -0.097 & -0.060 & 0.007 & 0.027 & -0.051 \\
\hline $\begin{array}{l}\text { Continuing Services } \\
\text { Ratio }\end{array}$ & $-0.284 *$ & 0.071 & 1 & $0.502^{*}$ & $0.125^{* *}$ & $0.123^{* *}$ & -0.036 & $-0.162 *$ & 0.065 & $0.332 *$ \\
\hline \%Local Revenues & 0.039 & -0.031 & $0.478^{*}$ & 1 & $0.361^{*}$ & $0.504^{*}$ & $-0.163 *$ & $-0.262 *$ & $0.427 *$ & $0.520 *$ \\
\hline Scope & $-0.149 *$ & $0.129 * *$ & $0.125^{* *}$ & $0.370^{*}$ & 1 & 0.058 & $-0.162 *$ & $-0.141^{*}$ & $0.513^{*}$ & -0.072 \\
\hline Location & 0.073 & -0.097 & $0.123^{* *}$ & $0.533 *$ & 0.058 & 1 & $-0.188^{*}$ & $-0.228^{*}$ & 0.084 & $0.637^{*}$ \\
\hline Tenure & 0.015 & -0.060 & -0.036 & $-0.193 *$ & $-0.162 *$ & $-0.188^{*}$ & 1 & $0.109 * *$ & -0.081 & $-0.160 *$ \\
\hline Gender & 0.038 & 0.007 & $-0.162 *$ & $-0.262 *$ & $-0.141^{*}$ & $-0.228^{*}$ & $0.109 * *$ & 1 & 0.018 & $-0.285^{*}$ \\
\hline HDI & -0.046 & 0.027 & 0.065 & $0.411^{*}$ & $0.513 *$ & 0.084 & -0.081 & -0.018 & 1 & $0.148 *$ \\
\hline Size & -0.008 & -0.065 & $0.287 *$ & $0.499 *$ & -0.094 & $0.622 *$ & $-0.167 *$ & $-0.289 *$ & 0.092 & 1 \\
\hline
\end{tabular}

Legend: * and ** indicate significance at $\mathrm{p}<0.01$ and $\mathrm{p}<0.05$ (based on two-tailed tests). See Table 2 for full definitions and descriptions for the study's dependent and independent variables. 
Correlation analysis results suggest that Tenure and HDI assist in explaining for \%Local Revenues. Tenure is negatively correlated with \%Local Revenues (at $\mathrm{p}<0.01$ ), while HDI is positively correlated with \%Local Revenues (at $\mathrm{p}<0.01$ ). Location and Size are positively significant correlated with Continuing Services ratio and \%Local Revenues. Conversely, Gender is negatively associated (at $\mathrm{p}<0.01$ ) with both Continuing Services Ratio and \%Local Revenues. There is also a statistically significant correlation between Scope and all of the dependent variables.

Correlations amongst the independent variables themselves indicates that the highest correlations are between Scope and HDI, with a coefficient of 0.513 $(p<0.01)$ for Pearson and Spearman correlations. This value is below the critical limit of 0.80 . Variance inflation factors calculated for all regressions reported in Table 5 for all independent variables provide further indication that multicollinearity is not a problem in the model estimations (Cooper \& Schindler 2003; Greene 1999; Hair et al. 1995) .

Independent Sample T-tests analysis and multiple regression techniques are conducted. Independent Samples T-Tests are carried out to examine the differences of financial condition between cities and regencies as well as between local government units located in Java and those located in other islands (see Tables 5 and 6). The results presented in Table 6 suggest that the means of financial condition proxies (Continuing Services Ratio and \%Local Revenues) are statistically different between those of cities and those of regencies. The mean of Continuing Services Ratio of cities is significantly higher (3.26) than that of regencies (2.31). Additionally, the mean of \%Local Revenues of cities is significantly higher (9.02\%) than that of regencies (5.13\%). Meanwhile, the

Table 5

Independent Sample t-test of Financial Condition between Local Governments Units with Scopes of Regency and City

\begin{tabular}{|c|c|c|c|c|c|}
\hline Scope & $\mathbf{N}$ & Mean & SD & t-value & Sig \\
\hline \multicolumn{6}{|l|}{ Quick Ratio } \\
\hline Regency & 265 & $1,029.96$ & $4,429.53$ & 1.657 & 0.099 \\
\hline \multirow[t]{2}{*}{ City } & 75 & 445.61 & $1,807.35$ & & \\
\hline & 340 & & & & \\
\hline \multicolumn{6}{|l|}{ Debt Ratio } \\
\hline Regency & 281 & 0.0096 & 0.0260 & -0.804 & 0.422 \\
\hline \multirow[t]{2}{*}{ City } & 80 & 0.0121 & 0.0188 & & \\
\hline & 361 & & & & \\
\hline \multicolumn{6}{|c|}{ Continuing Services Ratio } \\
\hline Regency & 324 & 2.31 & 1.30 & -3.685 & 0.000 \\
\hline \multirow[t]{2}{*}{ City } & 84 & 3.26 & 2.25 & & \\
\hline & 408 & & & & \\
\hline \multicolumn{6}{|l|}{ \%Local Revenues } \\
\hline Regency & 327 & 0.0513 & 0.0433 & -6.280 & 0.000 \\
\hline \multirow[t]{2}{*}{ City } & 85 & 0.0902 & 0.0528 & & \\
\hline & 412 & & & & \\
\hline
\end{tabular}

As a further check for multicollinearity, this study performs the model estimations reported in Table V, again after first excluding Scope and then HDI. The independent exclusion of each respective control variable does not significantly alter the findings reported in the main results. 
average of quick ratio for cities is moderately lower (445.61) than that of regencies $(1,029.96)$ at $\mathrm{p}<0.10$. This finding infers that city local governments have a lower liquidity position compared to regency local authorities.

Table 6 shows the result of independent samples T-tests carried out to examine the differences in financial condition between local government units located in Java and those of located in other islands. It suggests that the average of Continuing Services Ratio of local governments located in Java is significantly higher (3.38) than those of located outside Java (2.20) at $p<0.01$. In terms of the ability to earn revenues from local sources, the statistical results suggest that local governments situated in Java earned, on average, significantly (at $\mathrm{p}<0.01$ ) higher percentage of local source revenues compared to those of outside Java, which is $9.25 \%$ versus $4.77 \%$. Table 6 also suggests that the mean of the Debt Ratio is significantly lower (at $\mathrm{p}<0.01$ ) for local government units located in Java than those in the Non-Java sub-sample. It infers that local authorities located in Java have a relatively lower debt burden than local governments located in outside Java

Table 6, however, reveals that there is no statistically significant different in regard with the liquidity position between local government units located in Java and Non-Java.

Table 6

Independent Sample T-Test of Financial Condition Between Local Governments Unit Located in Java and Non Java

\begin{tabular}{|c|c|c|c|c|c|}
\hline Location & $\mathbf{N}$ & Mean & SD & t-value & Sig \\
\hline \multicolumn{6}{|l|}{ Quick Ratio } \\
\hline Non Java & 234 & 998.90 & $4,538.14$ & 0.641 & 0.522 \\
\hline \multirow[t]{2}{*}{ Java } & 106 & 685.08 & 3,257.39 & & \\
\hline & 340 & & & & \\
\hline \multicolumn{6}{|l|}{ Debt Ratio } \\
\hline Non Java & 255 & 0.0121 & 0.0267 & 2.743 & 0.006 \\
\hline \multirow[t]{2}{*}{ Java } & 106 & 0.0055 & 0.0177 & & \\
\hline & 361 & & & & \\
\hline \multicolumn{6}{|l|}{ Continuing Services Ratio } \\
\hline Non Java & 301 & 2.20 & 0.89 & -4.732 & 0.000 \\
\hline \multirow[t]{2}{*}{ Java } & 107 & 3.38 & 2.52 & & \\
\hline & 408 & & & & \\
\hline \multicolumn{6}{|l|}{ \%Local Revenues } \\
\hline Non Java & 305 & 0.0477 & 0.0439 & -9.122 & 0.000 \\
\hline \multirow[t]{2}{*}{ Java } & 107 & 0.0925 & 0.0437 & & \\
\hline & 412 & & & & \\
\hline
\end{tabular}

The results of multiple regression analysis for each financial condition proxy (Quick Ratio, Debt Ratio, Continuing Services Ratio and \%Local Revenues) are listed in Table 7, Panels A to D. 
Table 7

Results of Four Multivariate Regressions: Differing Measures of Condition

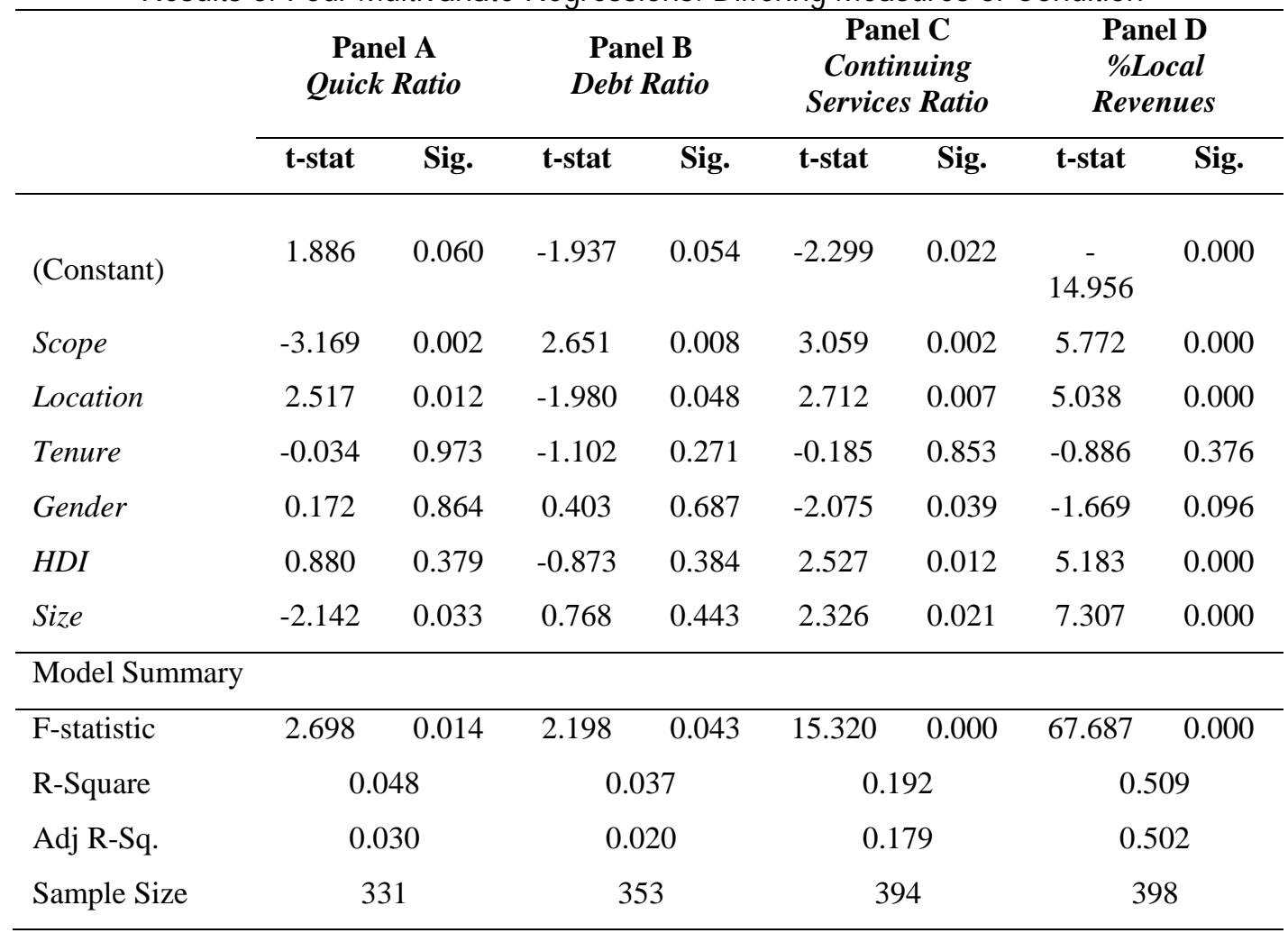

Legend: See Table 2 for full definitions and descriptions for the study's dependent and independent variables.

First, statistical results presented in Table 7 suggest that Scope is a predictor for all financial condition measures. Scope is positive and significant (at $\mathrm{p}<0.01$ ) associated with Debt Ratio, Continuing Services Ratio and \%Local Revenues. These results highlight that city local authorities are more likely to have: (1) higher proportion of debt to total assets; (2) superior unrestricted net assets to provide on going public services and; (3) a bigger proportion of revenues from local sources, than regency local authorities. Additionally, Scope is also a significant predictor for the Quick Ratio with a negative correlation. This infers that city local authorities have a lower quick ratio compared to that of regency local authorities.

Second, Table 7 also reports that Location is a statistically significant predictor for all the financial condition measures. Location is positively associated with Quick Ratio, Continuing Services Ratio and \%Local Revenues at $\mathrm{p}<0.05$, $\mathrm{p}<0.01$ and $\mathrm{p}<0.01$; respectively. These findings indicate that local governments domiciled in Java tend to have: (1) higher liquidity position; (2) stronger ability to finance their general services from their unrestricted net assets and; (3) bigger proportion of their revenues from local sources, than those outside Java local authorities. Additionally, Location has a negative and significant association with Debt Ratio. This finding suggests that Debt Ratio of local government units located in Java tends to be lower than that of the Non-Java local government units.

Third, Table 7 shows no significant association between Tenure and all of the financial condition variables. This finding suggests that neither local government units existing prior to decentralisation reform nor those existing 
following the decentralisation reform assist in explaining the local government financial condition. Fourth, Gender appears to be another predictor for Continuing Services Ratio and \%Local Revenues. Specifically, the coefficients on Gender are negative and significant at moderate $(\mathrm{p}<0.05)$ and bottom line $(\mathrm{p}<0.10)$ levels; respectively. These results infer that local government units with greater female populations tend to have stronger financial conditions than local government units that have greater male populations. Table 7 shows that HDI is positively associated with Continuing Services Ratio and \%Local Revenues at $\mathrm{p}<0.05$ and $\mathrm{p}<0.01$ respectively. These results imply that a local government unit characterised by a higher HDI tends to have stronger financial conditions than one characterised by a lower HDI. Therefore, a local government unit with a greater life expectancy, literacy rate and purchasing power parity tends to have stronger financial conditions. Finally, Size has a negative association with Quick Ratio (at $\mathrm{p}<0.05)$ and positive associations with Continuing Services Ratio (at $\mathrm{p}<0.05$ ) and $\%$ Local Revenues (at $\mathrm{p}<0.01$ ). These findings infer that a local government unit characterised by a bigger population is likely to have: (1) a lower quick ratio that is a lower liquidity position; (2) a better ability to finance its general services from its unrestricted net assets and (3) a bigger proportion of its revenues from local sources than that of with a smaller population. However, Size is not a statistically significant predictor for the Debt Ratio. The population of a local government unit does not assist in explaining the level of the ratio of its debt to its total assets.

\section{Discussion and Conclusion}

This study investigates differences in the financial condition and the association between demographic characteristics and the financial condition of Indonesian local governments. Demographic attributes including scope of entity, location, tenure, gender, human development index and local government size are measured to explain Indonesian local governments' financial condition. The financial condition is derived from Indonesian regencies' and cities' financial statements (the Statement of Budgeting Realisation and the Statement of Financial Position) for fiscal year 2007 audited by the Supreme Audit Body. It is proxied by four important financial measures: quick ratio, debt ratio, continuing services ratio, and percentage of local to total revenues.

Univariate and multivariate statistical analyses were conducted. The result of univariate statistical analysis provides insight into differences of local government financial condition, whereas the result of multivariate statistical analysis explains demographic characteristics that affect the financial condition of local government units.

The result of univariate analysis is statistically significant and suggests that Scope and Location of the local government units assist in explaining their differences in financial condition. The financial condition of the cities' local authorities is characterised by a higher proportion of debt to total assets, making use of more unrestricted net assets to provide ongoing public services, a larger proportion of revenues generated from local sources, and a lower liquidity position than those of the regency's local authorities. A plausible explanation is that there are differences in political, historical economic and administrative characteristics that evidently have the potential to impact on the local government financial condition. For example, it is argued that local governments 
encompassing metropolitan centres (cities) face different pressures than their counterparts in rural areas (regencies). As a result, city local authorities might have greater pressure to provide better quality public facilities and services compared to the regency local governments (Pilcher \& Van der Zhan 2008). Additionally, the location of local government units also assists in explaining the difference in the local governments' financial condition. Compared to local governments located outside Java, local governments situated in Java are significantly characterised by financial condition with a higher liquidity position, a stronger ability in making use of their unrestricted net assets to finance their general services, and a bigger proportion of their revenues from local sources. It is not surprising that local authorities located in Java perform better than local governments located outside Java. This result is consistent with the fact that even though Java constitutes only 6\% of Indonesia's total land area, it dominates the country's economy. Java contributes approximately 64\% of Indonesia's non-oil and gas gross domestic product (Hill 1998).

The results of regression analysis examining the association between demographic variables and each proxy of financial condition indicate that two demographic variables (Scope and Location) are consistently statistically significant in explaining local governments' financial condition. This finding is also consistent with the result of the univariate analysis. In term of Scope, it suggests that city local authorities tend to have higher debt ratios, better continuing services ratios, and bigger proportions of their revenues from local sources, as well as lower quick ratios than regency local authorities do. In regard to Location, this study finds that local governments domiciled in Java are more likely to have higher liquidity, stronger ability to finance their general services from their unrestricted net assets, bigger proportions of their revenues from local sources, and lower debt ratio than those outside Java local authorities.

Three other demographic variables (Gender, HDI, and Size) assist in explaining financial condition to some extents. The results of the regression analysis suggest that local governments with proportionately more females or with a higher HDI are stronger financially compared to those with proportionately fewer females or lower HDI. The higher the female population or the higher the HDI, the more likely the local governments have a strong ability in making use of their unrestricted net assets to finance their general services and making more revenue from local sources. This is an interesting finding; that gender is a factor enhancing the local authority financial condition. Further research is needed to provide a detailed explanation of this finding. Furthermore, the finding also suggests that the bigger the population of local governments, the better their financial condition will be. However, statistical findings suggest that Tenure is not a significant predictor for the local government financial condition.

In conclusion, this study aids those who seek to evaluate local governments' financial condition using accounting data. The demand for this data will encourage local authorities to enhance their accountability and financial transparency to meet their stakeholder's need. The rationale is that the trend following the decentralisation reform in Indonesia results in more researchers as well as other regional, national, or international institutions demand for information pertaining to the financial conditions of local government units for the purpose of making investment decision in the regions or cities. Additionally, Glaser and Denhardt (2000) observe that currently, citizens' perceptions of 
government are negative. One of the reasons is that citizens generally have difficulty accessing an objective assessment of the financial condition of local government units. Furthermore, this study provides empirical evidence that to achieve the objective of decentralisation in Indonesia (i.e. better delivery government services), policy makers need to consider some important factors. These are HDI, the number of people who live in a given local authority, as well as relevant factors attached to whether a local government is a city or regency and is located in Java or Non-Java.

Certainly, further studies will be needed to determine the best methodology for assessing the financial condition of local government. The use of ratio analysis for evaluation of the financial condition of local government is not free from criticism. For example, Chaney et al. (2002) argue that using financial ratios as indicators will be more useful if the ratios can be compared with appropriate benchmarks. They further state that although local governments have a similar characteristic in term of size, political status, or geographic location, they may not be comparable if they have different sources of revenues or operational issues or have chosen different accounting policies. Another limitation of the ratios analysis is if they are applied to highly complex business or state and local governments (Kamnikar et al. 2006). Future studies may seek to focus on refinements to the proxy measures both for dependent and independent variables. Other ratios can be expanded or developed, however, the selected ratios should achieve the desired level of neutrality (Kamnikar et al. 2006). It will also be potentially fruitful to research, for example, the impact of cultural elements on the financial condition of local governments.

\section{References}

Alm, J, Martinez-Vasquez, J \& Indrawati, SM 2004.Reforming intergovernmental fiscal relations and the rebuilding of Indonesia. Edward Elgar Publishing Ltd, Massachusetts, US. http://dx.doi.org/10.4337/9781845421656

Bantel, KA 1993, 'Top team, environment, and performance effects on strategic planning formality', Group \& Organizational Management vol. 18, no. 4, pp. 436-458. http://dx.doi.org/10.1177/1059601193184004

Brever, MB 1991, 'The social self: on being the same and different at the same time', Personality and Social Psychology Bulletin vol. 17, pp. 475-482. http://dx.doi.org/10.1177/0146167291175001

Brojonegoro, B 2001, 'Indonesian intergovernmental transfer in decentralization era: The case of general allocation fund', Working paper. Lembaga Penyelidikan Ekonomi dan Masyarakat-Fakultas Ekonomi Universitas Indonesia.

Boetti, L, Piacenza, M \& Turati, G 2010, 'Decentralization and local governments' performance: How does fiscal policy affect spending efficiency?' Working paper no. 11. Alma Universitas Taurinensis. Torino. Italy.

Carmeli, A 2004, 'Strategic human capital and the performance of public sector organizations', Scandinavia Journal of Management, vol. 20, pp. 375-392. http://dx.doi.org/10.1016/j.scaman.2003.11.003

Chaney, BA 2005, 'Analyzing the financial condition of the city of Corona, California: Using a case to teach the GASB 34 Government-Wide 
Financial Statements', Journal of Public Budgeting, Accounting \& Financial Management, vol. 17, no. 2, pp.180-201.

Chaney, BA, Mead, DM \& Schermann, K 2002, 'Financial reporting model: What it means for analyzing government financial condition', Journal of Government Financial Management Spring, pp. 27-31.

Chatman, JA \& Flynn FJ 2001, 'The influence of demography heterogeneity on the emergence and consequences of cooperative norms in work teams', Academy of Management Journal, vol. 44, no. 5, pp. 956-974. http://dx.doi.org/10.2307/3069440

Chodhury, S, Yamauchi, F \& Dewina, R 2009, Governance decentralization and local infrastructure provision in Indonesia. International Food Policy Research Institute, Poverty, Health and Nutrition Division, IFPRI.

Cooper, DR, \& Schindler, PS 2003, Business Research Methods, 8th edn, McGraw-Hill, Irwin, Boston.

Cox, T, Lobel, S \& McLeod, P 1991, 'Effects of ethnic group cultural differences on cooperative and competitive behavior on a group task', Academy of Management Journal, vol. 34, pp. 827-847. http://dx.doi.org/10.2307/256391

Frink, DD, Robinson RK, Reithel B \& Arthur, MM 2003, 'Gender demography and organizational performance: A two-study investigation with convergence', Group \& Organizational Management, vol. 28, no. 1, pp. 127-147. http://dx.doi.org/10.1177/1059601102250025

Glaser, MA \& Denhardt RB, 2000, 'Local government performance through the eyes of citizens', Journal of Public Budgeting, Accounting \& Financial Management, vol. 12, no. 1, pp. 49-73.

Goldberg, CB 2005, 'Relational demography and similarity-attraction in interview assessments and subsequent offer decisions', Group \& Organizational Management, vol. 30, no. 6, pp. 597-624. http://dx.doi.org/10.1177/1059601104267661

Greene, W 1999, Econometric analysis, 4th edn. Prentice-Hall, Inc. New York, U.S.

Groves, SM, Godsey, WM \& Shulman, MA 1981, 'Financial indicators for local government', Public Budgeting \& Finance, Summer, pp. 5-19. http://dx.doi.org/10.1111/1540-5850.00511

Gruenfield, DH, Mannix, EA, Williams, KY \& Neale MA, 1996, 'Group composition and decision making: How member familiarity and information distribution affect process and performance', Organizational Behavior and Human Decision Processes, vol. 67, pp. 1-15. http://dx.doi.org/10.1006/obhd.1996.0061

GTZ 2003, Decentralization in Indonesia since 1999: An overview, http://www.gtzfdm.or.id/dec_in_ind.htm, accessed 7/2/2007.

Hair, JF, Anderson, RE, Tatham, RL \& Black, WC 1995, Multivariate data analysis, 4th edn. Prentice-Hall, Inc, Englewood Cliffs, U.S.

Hill, H 1998, 'The challenge of regional development in Indonesia.', Australia Journal of International Affairs, vol. 52, no. 1, pp. 19-34. http://dx.doi.org/10.1080/10357719808445235

Hogg, MA \& Terry DJ 2000, 'Social identity and self-categorization process in organizational contexts, Academy of Management Review, vol. 25, pp. 121-140. 
Hughes, JW \& Laverdiere, R 1986, 'Comparative local government financial analyses', Public Budgeting \& Finance Winter, pp. 23-33. http://dx.doi.org/10.1111/1540-5850.00726

Judge, TA \& Ferris, GR 1993, 'Social context of performance evaluation decisions', Academy of Management Journal, vol. 36, pp. 80-105. http://dx.doi.org/10.2307/256513

Kamnikar, JA, Kamnikar, EG \& Deal KH 2006, 'Assessing a state's financial condition', The Journal of Government Financial Management, vol. 55, no. 3, pp. 31-36.

Lawrence, BS 1997, "The black box of organizational demography', Organization Science, vol. 8, no. 1, pp. 1-22. http://dx.doi.org/10.1287/orsc.8.1.1

Levine, J \& Resnick, L 1993, 'Social foundations of cognition', Annual Review of Psychology, vol. 44, pp. 585-612. http://dx.doi.org/10.1146/annurev.ps.44.020193.003101

Mannix, E \& Neale, MA, 2005, 'What differences make a difference', Psychological Science in the Public Interest, vol. 6, no. 2, pp.31-55. http://dx.doi.org/10.1111/j.1529-1006.2005.00022.x

Mead, DM 2001, An analyst's guide to governmental financial statements: Government Accounting Standards Board.

Nikolai, LA \& Bazley, JD 1994, Intermediate accounting, 6th edn, South-Western Publishing Co., Cincinnati, Ohio.

Pallis, AA \& Syriopoulos, T 2007,' Port governance models: Financial evaluation of Greek port restructuring', Transport Policy, vol. 14, pp. 232-246. http://dx.doi.org/10.1016/j.tranpol.2007.03.002

Pfeffer, J 1997. New directions for organization theory: Problems and prospects: Oxford University Press, New York.

Pilcher, R \& Van der Zhan, M 2008, 'Local government management of discretionary and specific accruals', in European Accounting Association Annual Conference. Rotterdam, Netherlands, April 2008.

President of the Republic of Indonesia 2005, Introduction of government accounting standards: Attachment 1 - The Government Regulation of the Republic Indonesia Number 24 Year 2005.

Ray, D \& Goodpaster, G. 2003. Indonesian decentralization, in D. Kingsbury \& $\mathrm{H}$. Aveling (eds), Autonomy and Disintegration in Indonesia, http://books.google.co.id/books?id=Is6RoG2GUYC\&pg=PA94\&lpg=PA9 4\&dq=otonomy+daerah,+Indonesia\&source=web\&ots=Log5HBB4u8\&Si $\mathrm{g}=$ BoeME7c3DCDEAYuOXQTc-AiIQoK\&hl=en\#PPA63,MI, accessed 8/9/2007.

Roszak, D 2006, 'Smart combination of factors can earn even small hospitals top credit rating', Hospital \& Health Networks, vol. 80, no. 2, p.66.

Statistics Indonesia 2005, Statistics Indonesia 2005, http://demografi.bps.go.id/versi2/index.php?option=com_tabel\&task=sho w\&Itemid=165\&lang=en, accessed 7/2/2007.

Stevens, JM \& McGowan, RP 1983, 'Financial indicators and trends for local governments: A state-based policy perspective', Policy Studies Review vol. 2, no. 3, pp. 407-416. http://dx.doi.org/10.1111/j.15411338.1983.tb00726.x

Stevens, PA 2005, 'Assessing the performance of local government', National Institute Economic Review, vol. 193, pp. 90-101. 
http://dx.doi.org/10.1177/0027950105058565

Sukma, R, 2003. Conflict management in post authoritarian Indonesia, in D.

Kingsbury \& H. Aveling (eds). Autonomy and Disintegration in Indonesia, http://books.google.co.id/books?id=Is6RoG2GUYC\&pg=PA94\&lpg=PA9 $4 \& \mathrm{dq}=$ otonomy + daerah, + Indonesia\&source=web\&ots $=$ Log5HBB4u8\&Si $\mathrm{g}=$ BoeME7c3DCDEAYuOXQTc-AiIQoK\&hl=en\#PPA63,MI, accessed $8 / 9 / 2007$.

Suwarno 2007, 'Analisis kemampuan keuangan pemerintah daerah dengan finansial rasio terhadap neraca pemerintahan daerah', in Pidato Pengukuhan Widyaiswara Utama: Badan Pendidikan dan Pelatihan Departemen Dalam Negeri Republik Indonesia.

Thrane, C 2008, 'Earnings differentiation in the tourism industry: Gender, human capital and socio-demographic effects', Tourism Management vol. 29, pp. 514-524. http://dx.doi.org/10.1016/j.tourman.2007.05.017

Turner, JC \& Oakes, PJ 1986, 'The significance of the social identity concept for social psychology with reference to individualism, interactionism, and social influence', British Journal of Social Psychology, vol. 25, pp. 237252. http://dx.doi.org/10.1111/j.2044-8309.1986.tb00732.x

USAID 2008, Good governance brief - citizen engagement and participatory governance. Local Government Support Program.

Usman, S 2001, 'Indonesia's decentralization policy: Initial experiences and emerging problems', in The Third Euroseas Conference Panel on Decentralization and Demogration in Southeast Asia. September 2001, London.

Watkins, AL 2000, 'Hospital financial ratio classification patterns revisited: Upon considering nonfinancial information', Journal of Accounting and Public Policy, vol. 19, pp. 73-95. http://dx.doi.org/10.1016/S02784254(99)00025-3

Wei, LQ, Lau, CM, Young, MN \& Wang, Z 2005, 'The impact of top management demography on firm performance in China', Asian Business \& Management, vol. 4, pp. 227-250. http://dx.doi.org/10.1057/palgrave.abm.9200130

Young, MN \& Buchholtz, AK 2002, 'Firm performance and CEO pay: Relational demography as a moderator', Journal of Management Issues vol. 14, no. 3, pp. 296-313.

Zeller, TL, Stanko, BB \& Cleverley, WO 1996, 'A revised classification pattern of hospital financial ratios', Journal of Accounting and Public Policy, vol. 15, pp. 161-182. http://dx.doi.org/10.1016/0278-4254(96)00014-2

Zenger, TR, \& Lawrence BS 1989, 'Organizational demography: The differential effects of age and tenure distributions on technical communication', Academy of Management Journal, vol. 32, pp. 353-376.

http://dx.doi.org/10.2307/256366 